\title{
A Nexus between Corporate Social Responsibility Disclosure and its Determinants in Energy Enterprises
}

RAHIL AHMED ( $\sim$ rahilirfan@gmail.com )

Shanxi University of Finance and Economics https://orcid.org/0000-0001-7719-3398

GuoHao Zhao

Shanxi University of Finance and Economics

Keywords:

Posted Date: August 19th, 2020

DOI: https://doi.org/10.21203/rs.3.rs-56112/v1

License: (c) (i) This work is licensed under a Creative Commons Attribution 4.0 International License.

Read Full License

Version of Record: A version of this preprint was published at Journal of Business \& Industrial Marketing on October 1st, 2021. See the published version at https://doi.org/10.1108/JBIM-07-2020-0359. 


\section{Abstract}

The authors have requested that this preprint be removed from Research Square. 